\title{
The Exploration of Empathy of the Inclusive Elementary School Teacher in Denpasar
}

\author{
Aritya Widianti, N. Trisna Aryanata, A.A.I. Mira Pramitya \\ Department of Psychology of Health Sciences Institute of Medika Persada Bali \\ Bali, Indonesia \\ ari.tya.widianti@gmail.com
}

\begin{abstract}
Empathy is an activity to understand what other people are thinking and feeling by engaging cognitive, affective and communication skills without losing self-control. This research explores empathy in inclusive elementary school teachers in Denpasar. This research uses qualitative Focus Group Discussion (FGD) method toward six inclusion elementary schools in Denpasar. The results showed that empathy respondents were divided into three major themes. The themes are self-conditioning, self-control and empathy expression. Empathy is important in teaching and learning. Empathy will affect the relationship between teachers, students and parents. Empathy can play an important role in the integration of children with special needs in the educational process. Children with special needs are not marginalized.
\end{abstract}

Keywords- empathy; inclusion elementary school; Focus Group Discussion; children with special needs.

\section{INTRODUCTION}

The existence of children with special needs reaches 10 million children in Indonesia [1]. Meanwhile, in Bali, the amount of children with special need receiving education in inclusion school is around 1.067 children [2]. Law of Republic of Indonesia number 20 of 2003, regulates the system of national education. This Law provides a legal standard in implementing inclusion school. In addition, this is a legal form that children with special need have the right to gain intention and education certainty from the government. Inclusion school, then, becomes a real instrument of education for children with special need. The preparedness of teacher and school administrator dealing with children with a special need is the main focus of this research.

The teacher should have three attitudes, namely cognitive, affection, and behaviour [3]. The attitude toward children with special need in the classroom, teacher's attention to the need of each student in the classroom, the availability of the facility in order to support the effectiveness of inclusion class. Empathy is a process in which ones are considerate toward other's condition as if he is on other person' shoes [4]. Empathy is the ability to ponder objectively about the deepest life of another person. The high process of empathy is affected by the intellectual capacity to consider what others think and feel, or in another word, it is an ability to understand other people. Empathy relates to understanding and feeling, meanwhile, sympathy relates to action. Empathy is not only expressing our feeling for what is happening outside our life, but it also understands the object that is targeted. That understanding includes to pour out feeling and thinking. Empathy process happens due to the communication of our thinking and feeling toward others thinking and feeling. While the empathy process happens deeply, the sympathy process is the otherwise [4].

This research is about to find out the dynamic of the empathy of Inclusion Primary School teacher in interpreting children with special need, and their assignment as teaching in Denpasar. This research is expected to contribute knowledge in the psychological field, especially education psychology and another scientific field. This research is also expected to give additional knowledge toward teachers in Inclusion Primary School, so that, they will understand that teaching child with a special need is not merely a profession, but it requires empathy in order to gain success in the process of self-understanding of the student.

\section{METHOD}

This research is descriptive qualitative research using focus group discussion method (FGD). Qualitative approach becomes the accurate choice for this research due to this research is intended to comprehend in depth the teacher's understanding of empathy related to their work experience in educating children with special needs. The basic principal of FGD aligns to the framework of qualitative research that is, observing humans self dynamic within their natural way of thinking, in which it is often related to values of life from the living environment [5]. This research is also involved nine participants whose their job is a primary school teacher in inclusion school in Denpasar area. The selection of sample is purposive, meaning the researcher determine participant criteria based on purpose/objective and literature review of research. Below are the participant criteria of this research:

- Primary inclusion school teacher with a minimum of two years teaching experiences,

- Inclusion primary school where the participant working is in Kotamadya Denpasar,

- Willing to participate in the data collection process until it is stated to be complete. 


\section{RESULT AND DISCUSSION}

It can be found in this research, three big themes in empathy process experienced by respondent. Those three empathy processes are: experiencing self-conditioning, selfmanaging, and empathy expression.

\section{A. Self-conditioning}

Self-conditioning is a respondent effort to self-prepared in dealing with children with special need, which includes respondent learning process in order to produce new experiences. From all nine inclusion primary schools that attend FGD, they gave various statements. In the early stage assisting children with special need, their experiences were varied. Most of the respondent was jolted, did not believe what they had dealt with, even though there were few respondents viewed it as a normal condition due to they considered children with special need as a first grade student in primary school who need to be guided by their teachers. From the momentarily jolted and disbelief by the condition of the student, the respondent gradually began to find the rhythm in assisting children with special need in the classroom.

"At that moment, I was like... God, what happened to Your tiny human being creation... because I have never seen like this before."

From jolted and disbelieve felt by the respondent, the following action was to find out the solution on how to assist children with special need along with the professional expert.

"I consult a psychologist, I wonder about hyperactive children, I was invited to the seminar.'

\section{B. Self-managing}

Self-managing is the act of controlling, organizing, responding and, implementing the process and the methods in order to perform assistance activities toward children with special need in the learning process. In assisting children with special need, respondent requires an abundance of patience. Besides, in giving material and assessing the result, the respondent need to accommodate to the condition of children with special need. There are few ideas emerge from a few respondents, "If I were the parents of this children." The respondents consider children with special need as their friends, with wholehearted assisting the process, take a deep breath when facing difficulty, be compassionate, and need to prepare for anything when they are going to teach. The respondent is also stated that they have to able to self-manage. Their voice is soft and tries to involve children with special need in the learning process.

"This is all about heart, it means that we have to sincere when we teach this kind of kid. If it is not us, who else? Frankly to say, at that time I got bitten, I want to stop right a way... but my heart... I empathize to that children because they also God's creature, it can be said that... they are human too."

"If we have a heart, I am sure I can do it."

\section{Empathy expression}

Empathy expression is a process of revealing, declaring, showing or expressing intention, idea, and feeling through body language, face mimic, and words in implementing the learning process of children with special needs. All respondent show various empathy expression. When a child with special need was angry, the respondent gave some time for him to be alone. Respondent gave physical contact such as stroking head, holding hand or shoulder and acted calmly even when a child with special need behave maladaptively. Respondent continued to act as a friend even though child with special need behave maladaptively, gave a chance for those who were considered capable of joining in a regular class, gave an opportunity for them to channel all their energy by giving some time to run around the field. Respondent only allowed children with special need to take an exam from school, gave them a lower target compare to their peers, involved them in each activity, gave dispensation mark, gave positive utterance so that they would be motivated, spent more time with them in learning assistance, educating school environment, worked together with their parents and other professional expert. Respondent also treated them in accordance with their capability/portion??

"If they are not able to follow the learning material, they will be expelled from the classroom and be assisted with speciality teacher. If there is skill activity that requires togetherness, a child with special need must be included."

This research shows that respondents experience three big themes of empathy. Starting from self-conditioning, then selfcontrolling, and lastly is empathy expression. Respondentsconditioning of Inclusion Primary School in assisting children with special needs is varied. The inexplicable condition in assisting a child with special need in the classroom becomes more understandable. The respondents of Inclusion Primary School receive an updated understanding of how to assist children with special need. Respondents also are conditioned by the existence/presence of children with special need in their class.

When the respondent is in the self-conditioning stage, thus empathy expression emerges. There is numerous empathy expression that refers to one or all empathy components, namely: cognitive component, effective component, cognitive and affective component, and communicative component [6]. In the beginning, respondents experienced bewilderment, disbelief, and even wanted to give up when handling children with special needs. However, respondents employed cognitive component in order to find the best solution in assisting children with special needs. Respondent increases their knowledge by reading a lot of literature, attending seminar and training.

Empathy as the affective aspect refers to the ability to adjust the emotional experience toward other people. Empathy aspect consists of sympathy, sensitivity, and sharing difficulties experienced by other people, in other words: feeling close toward the difficulties of others which is imagined as if it is experienced by oneself [6]. Respondents indicated that they have this kind of component by showing the feeling "If I had a child with special needs" Respondents imagine as if they were the parents of children with special needs. Sensitivity comes 
along when the respondents are hearing the experience from the parents of children with special needs, as well as the abundance effort that had been done by them up to the moment. Good communication between teacher and parents of children with special needs creates a form of connection of cognitive and affective components.

Empathy process consists of four stages, namely: antecedents, processes, interpersonal outcomes and intrapersonal outcomes [6]. Empathy process as explained by Davis is showed by the diagram above. Antecedents are a condition that precedes the occurrence of empathy process. It consists of observer characteristic, target, or situation occurring at that time. Each person has different empathy capacity; some people have high empathy capacity, others are otherwise [6]. The result of this research can be categorized in selfconditioning theme. There were few respondents who felt jolted, panic, and confused in the early stage they started to assist children with special needs. On the other hand, there was also some respondent who felt common because they considered children with special need as a lower class who really need assistance and guidance. Afterwards, there are processes, which each of the respondents share their various experiences. There are some respondents asking the teacher who is accustomed to assisting children with special needs, increasing their knowledge by reading literature, consulting to the psychologist as well as attending the seminar. However, on the other hand, there are few respondents that consider children with special needs as children who can

Intrapersonal outcomes are shown by the respondent reaction who initially wanted to give up but then decided to keep assisting children with special needs. Fortunately, the respondent turns out to be responsible in assisting them until they can be successful in society. There will be sadness if they fail. Thus, all the respondents came into conclusion that there should be patience and compassion in assisting children with special needs. In this research, this process is categorized as a self-managing theme. Interpersonal outcomes bring an effect toward the relationship between respondents and children with special needs. The tangible form of this process is the emergence of helping behaviour. In addition, the better the accuracy of the empathy, the less aggressive behaviour will occur [6]. This Davis' empathy process is in accordance with the third theme, namely: empathy expression.

Increasing effectiveness from school intervention is a relation between parenting at home and at school. One of the cooperation form in inclusion school is communicating various child development into the form of liaison book between parents and teacher for every once in a week. Another cooperation form between teacher and parents of a child with a special need is training. The aim of this training is to adjust the parenting form that suitable with the characteristic of children with special needs so that the parents will receive strategy when tackling the children that focus on specific problematic behaviour [7]. From six schools that sent their representative to attend FGD, it is only two schools (both are private schools) that had distinctive rooms where learning process for children with special need takes place.
In addition to the distinctive room, the representatives from both schools are also mentioned particular terminologies such as ABA, IEP, and occupation therapy. One public school receive more than one training from government of Bali. Those three representatives are more active in explaining their method when assisting children with special needs than the others. Other representatives have a tendency explaining their assistance to children with special need by considering them as an ordinary little kid. Yet, there are also few representatives who give assessment based on the capability of children with special need in writing question. Most of the schools accept children with special need without an official document from the experts regarding developmental disorder of that children. Therefore, there is a statement that children who are not able to make eye contact is regarded as autism. By consulting to the expert, reading a lot of literature, as well as attending training/seminar will broaden respondents' knowledge so that it increases their capability in assisting children with special needs.

\section{CONCLUSION}

From this research, it can be found that the dynamics of an inclusion school teacher in understanding their task/ responsibility and children with special needs, produce three big themes. Three big themes in this research are selfconditioning, self-managing, and empathy expression. All of the nine respondents show their empathy in assisting children with special needs. However, each respondent shows the various depth of empathy and empathy expression.

The knowledge of each respondent is different. This is reflected from a particular respondent who willingly asks the question, read a lot of books about children with special needs, and attend seminar or training. As a result, this kind of respondent has a better understanding in assisting children with special needs. That respondents recognize how to create IEP, teach self-development for that children. In addition to that, the respondent can employ a gift system (giving sticker that can be exchanged into stationary) in order to motivate children. The respondent is also put the children based on the portion (or capability), meaning they should not always be assisted).

\section{SugGestions}

An inclusion school teacher is suggested to broadening the knowledge related to children with special need by attending the seminar, workshop, and joining sharing section with teachers who is accustomed assisting children with special needs. The schools are suggested to carrying out regular training for teachers so that they can more comprehend how to tackle children with special needs in the classroom, and schools can propose a proposal/aid to government or private institution so that they can obtain regular training.

\section{REFERENCES}

[1] K. P. Perempuan, Panduan penanganan anak berkebutuhan khusus bagi pendamping (orang tua, keluarga dan masyarakat), Jakarta: Deputi Bidang Perlindungan Anak Republik Indonesia, 2013.

[2] N. C. Wijaya, I. G. A. A. Suryawati, A. D. Pradipta, "Pola Komunikasi Guru di Yayasan Peduli Autisme Bali dalam Meningkatkan Interaksi Sosial Anak Autistik," E-Jurnal Medium, vol 1, no 1, 2017. 
[3] J. M. Leatherman1, and J. A. Niemeyer, "Teachers' attitudes toward inclusion: Factors influencing classroom practice," Journal of Early Childhood Teacher Education, vol 26, no 1, pp. 23-36, 2005.

[4] C. O'Hanlon, Educational inclusion as action research interpretive discourse. UK: McGraw-Hill, 2003.
[5] H. Herdiansyah, Metodologi penelitian kualitatif untuk ilmu psikologi, Jakarta: Salemba Humanika, 2015.

[6] T. Taufik, Empati pendekatan psikologi sosial, Jakarta: PT. Raja Grafindo Persada, 2012.

[7] B. Bethayana, "Deskripsi karakteristik anak berkebutuhan khusus (ABK) di sekolah inklusi," unpublished. 